Ankara Üniversitesi Eğitim Bilimleri Fakültesi Dergisi

Yll: 2020, Cilt: 53, Sayl: 2, 723-749

DOI: 10.30964/auebfd.643667, E-ISSN: 2458-8342, P-ISSN: 1301-3718

Türk ve İngiliz Atasözlerinde Eğitsel Değerler

\begin{tabular}{lccc}
\hline MAKALE TÜRÜ & Başvuru Tarihi & Kabul Tarihi & Yayın Tarihi \\
Araştırma Makalesi & 06.11 .2019 & 08.07 .2020 & 08.07 .2020 \\
\hline
\end{tabular}

Bayram Așılıoğlu (iD ${ }^{1}$ ve Berivan Tokur Üner (iD) ${ }^{2}$

Dicle Üniversitesi

\begin{abstract}
Öz
Bu araştırmanın amacı Türk ve İngiliz atasözlerini eğitsel değerler açısından karşılaştırmalı olarak incelemektir. Araştırma nitel araştırma desenlerinden doküman incelemesiyle gerçekleştirilmiştir. Verilerin toplanmasında Türk ve İngiliz uluslarına ait atasözlerinin yer aldığ1 sözlükler incelenmiş̧tir. Araştırmada öncelikle eğitimle ilgili iletiler sunan atasözleri belirlenmiştir. Daha sonra da belirlenen bu atasözlerindeki eğitsel iletiler eğitim ile ilgili konulara göre kodlanmış ve belirlenen kodlardan birbiriyle ilişkili olanlar seçilerek temalar oluşturulmuştur. Bu çalışma kapsamında incelenen Türk ve İngiliz atasözlerinde eğitim ile ilgili iletilerin, çocukluk çağında verilen eğitimin önemi; akıl ve bilgi sahibi olmanın bireyin yaşamındaki yeri ve eğitimle ilişkisi; güdülenmenin öğrenmeye etkisi; yaparak-yaşayarak ögrenme; işbirliği, etkileşim ve model almanın yararları; eğitimde ödül ve ceza gibi kavramlar üzerinde yoğunlaştığı görülmüştür. Araştırmada, yaşamboyu öğrenme konusuna İngiliz atasözlerinde yer verilirken Türk atasözlerinde bu konuya değinilen örneklere rastlanmamıştır. Sonuç olarak, her iki ulusa ait atasözlerinin, günümüzde yaygın olarak kabul gören eğitim anlayışları bakımından, büyük ölçüde benzer düşünceler içerdiği anlaşılmıştır.
\end{abstract}

Anahtar sözcükler: Atasözü, eğitsel değerler, kültür, yaşamboyu öğrenme.

${ }^{1}$ Sorumlu Yazar: Doç. Dr., Ziya Gökalp Eğitim Fakültesi, Eğitim Bilimleri Bölümü, Eğitim Programları ve Öğretim Anabilim Dalı, E-posta: bayramasilioglu @ gmail.com, https://orcid.org/0000-0002-2425-0624 ${ }^{2}$ Doktora Öğrencisi, Eğitim Bilimleri Enstitüsü, Eğitim Bilimleri Anabilim Dalı, Eğitim Programları ve Öğretim BilimDalı, E-posta: berivan.tokur@hotmail.com, https://orcid.org/0000-0002-3777-5606 
Toplumların dillerinde, yaşadıkları olaylardan çıkardıkları sonuçları kısa ve kolay anlaşılır bir biçimde belirttikleri söz kalıpları vardır. Az sözle çok şey anlatan bu söz kalıplarından biri de atasözleridir. Atasözleri; uzun deneme ve gözlemlere dayanılarak söylenmiş ve halka mal olmuş, öğüt verici nitelikte sözlerdir (Türk Dil Kurumu-TDK, 2011). Kamuca benimsenmiş düşünceleri bilgece, öğüt, adet, gelenek, inanç niteliğinde ve genel kural olarak belirten bu sözlerin çoğu değişmeceli bir anlam içerir. Bazı atasözleri tanıma aykırı düşen nitelikte yanlış öğüt, yanlış gözlem belirtiyor gibi görünse de aslında yanlışın farkına vardırma ve doğruyu sezdirme gibi özelliklere sahiptir (Özdemir, 1984).

Dilin ustaca kullanıldığı söz kalıpları olan atasözleri; güzel buluşlarla, ilgi çekici nüktelerle, ince alaylarla, kimi zaman da sert taşlamalarla dolu bir içeriğe sahiptir. Benzetmelerle, söz sanatlarıyla ve güzel buluşlarla dolu anlatımlarıyla ulusların zekâlarındaki keskinliği, hayallerindeki genişliği, duygularındaki inceliği yansıtır (Aksoy, 1998). Mieder (2004), bu özelliklerinden dolayı atasözlerinin bütün özelliklerini kapsayan bir tanım yapmanın güçlüğünü belirtmekle birlikte atasözlerini biçimsel bir yapısı olan ve yorum içeren, bilgeliği, gerçeği, ahlaki ve geleneksel görüşleri değişmeceli olarak anlatan kalıplaşmış, anımsanması kolay olan ve kuşaktan kuşağa aktarılan kısa sözler olarak tanımlar.

Bir ulusun maddi ve manevi kültürünü anlatan ürünler olarak atasözleri (Aksan, 2014), aynı zamanda içinde doğduğu dilin gücünü ve anlatım olanaklarını yansıtır. İnsanlar düşüncelerinin doğruluğunu atasözlerinden örnekler vererek kanitlamaya çalışırlar (Aksoy, 1998). Atasözlerinin sözlü ve yazılı iletişimde uygun durumlarda kullanılması anlatıma etki ve güç katar (Aşılıŏlu, 2009). Dolayısıyla atasözleri günlük iletişimin önemli bir parçasıdır. Özellikle sözel iletişimde; politik söylemlerde, şarkı ve türkü sözlerinde, gazete manşetlerinde, kitap başlıklarında, reklam sloganlarında ve canlandırma sinemasında yaygın olarak kullanılmakta (Gibbs $\mathrm{Jr}$, 2001) ve bu özelliği nedeniyle insanlığa ilişkin genel deneyimlerin, ahlaki değerlerin ve toplumsal becerilerin kuşaktan kuşağa aktarılmasını sağlayan araçlardan biri olmaktadır.

Akıl, bilgelik, deneyim, öğrenme, otorite ve öğretmen sorunları gibi pek çok konuyla ilgili özel atasözleri bulunmaktadır. Atasözleri modern toplumlarda, özellikle aile üyeleri arasında ve okulda eğitsel araç olarak önemli işlevler yerine getirmektedir (Mieder, 2004). Söz konusu işlevlerinden dolayı atasözleri; bilge kişileri olduğu kadar profesyonel olmayanları da etkilemekte; antropologlar, psikologlar, halkbilimciler, dilbilimciler, toplumbilimciler, eğitimciler, psikiyatristler, tarihçiler, din eğitimcileri, yazına ilgi duyanlar, avukatlar, reklam yöneticileri, yönetim danışmanları gibi farklı alanlarla uğraşan insanlar tarafindan araştırılmakta ya da kullanılmaktadır (Honeck, 1997).

Toplumdan topluma farklılık gösteren, neyin iyi ya da kötü olduğu; neyin başarı ya da başarısızlık sayılacağı bilgisi toplumsal bağlam içinde kavramsallaşır (Büyükkantarcıŏ̆lu, 2006) ve insan ilişkilerine dil aracılığı ile yansıyarak gerçeklik kazanır. Dolayısıyla toplumsal gerçeği araştırırken dildeki gizli ya da açık olan 
anlamları incelemek gerekir (Hare-Mustin, 1994 akt. Gür, 2013). Söz konusu incelemelerin yapılabileceği kaynaklardan biri de atasözleridir. Atasözleri ulusların çeşitli konularla ilgili duygularını, düşüncelerini, değerlerini, beklentilerini yansıtır. Genellikle ulusal bir içeriğe sahiptir. Bununla birlikte bazı atasözlerinde evrensel değerlerle ilgili düşünceler ağır basar. Ayrıca benzer özelliklere sahip olan ulusların atasözlerinde de benzerlikler görülür. Hatta bir ulusun atasözü varlığ içinde başka uluslardan alınmış atasözleri ile karşılaşmak olasıdır. Örneğin; Oy’un (1972), "Tarih Boyunca Türk Atasözleri” adlı eserinin Kitab-1 Atalar (Fatih Kitaplığı Yazması) Atasözleri başlıklı bölümünde, MS 7. ve 8. yüzyıllarda Arap Yarımadası'nda yaşadığı kabul edilen mizah karakteri Cuha ile ilgili atasözü vardır.

Dünyada konuşulan dillerin çoğunda başka dillerdekine benzer ya da aynı anlama gelen atasözleri bulunmaktadır. Lauhakangas (2007), bir kültüre ait atasözlerinin benzerlerinin ya da aynısının başka ulus ya da uluslar tarafından kullanılmasını, atasözlerinin yansıttığı düşüncelerin çoğu kez aynı noktada kesişmesine bağlar. Söz konusu kesişimin örnekleri İngiliz atasözlerinde görülmektedir. Ivanov ve Petrushevskaia'ya göre (2015), İngiliz atasözleri köken bakımından yerli ve ödünç alınmış olarak ikiye ayrılmaktadır. Yerli atasözleri; İngiliz halkının dilindeki sözlü ve yazılı yapıtlardan (özellikle William Shakspeare'in eserleri ve kutsal kitaptan) alınmış olanlardır. Bu atasözlerinin \% 59'u İngiliz İngilizcesi; \% 2.5 'u da Amerikan İngilizcesi kökenlidir. Bunların dışında kalan \% 38.5'i başka dillerden ödünç alınmıştır. Bunların \% 20'si Latince; \% 7'si Fransızca; \% 6'sı Eski Yunanca; \% 1.5'u İtalyanca; \%1.5'u İskoçcadan İngilizceye geçmiştir. Geriye kalan \% 2.5'u da küçük oranlarda olmak üzere, Almanca, İspanyolca, İrlandaca, Çince ve Farsça gibi dillerden alınmıştır.

Atasözleri genellikle eğitsel içeriğe sahiptir. Yüzyıllardır ahlaki değerlerin ve toplumsal becerilerin gelecek kuşaklara öğretilmesinde atasözlerinden yararlanılmıştır. Atasözleri, bir olay ya da olguyu az sözle anlatmak, anlatılanları daha etkili ve inandırıcı kılmak için başvurulan anlatım yollarından biridir (Özdemir, 1984). Bilgece söylenmiş bu sözler, çocuk yetiştirmeden okullardaki dil ve din öğretiminde ve insanlığa dair genel deneyimlerin onlara kazandırılmasında uzun zaman öğretici araçlar olarak kullanılmışlardır. Modern toplumlarda özellikle aile üyeleri arasında ve okulda eğitim aracı olarak önemli bir yere sahip olan atasözleri, temel olarak tüm dillerin ortak özelliklerine sahip oldukları için insan doğası ve dünya hakkındaki bilgi ve aklı anlatmada çok etkili araçlardır (Mieder, 2004). Bir ulusun atasözlerinde o ulusun kültürü ile ilgili bilgiler ve kültürü oluşturan değerler, inançlar, yaşama biçimi ve kısaca insanların yapıp-ettiği her şey bulunabilir. Dolayısıyla bir ulusun eğitim anlayışı ile ilgili bilgi ararken başvuracağımız kaynaklardan biri de o ulusun atasözleridir.

Alanyazında, eğitimle ilgili Türk atasözleri üzerine yapılmış çok sayıda araştırmaya rastlanmıştır. Bunlardan belli başlıları: Aksan, 2014; Aşılıoğlu, 2009; Bulut, 2013; Karakuş ve Keçe, 2012; Kurt, 1997; Sönmez, 2014; Taşdelen, 2000; Yaşar, 2007'dir. Bu araştırmalarda incelenen Türk atasözlerine göre; Türk eğitim 
sisteminin dayandığı zihniyet yapısı, eğitim ve bilgi kavramları, Türkçe öğretimi ve eğitim değerleri, çevre eğitimi, sosyal bilgiler öğretimindeki değerler, eğitimin önemi, amaçları, zamanı, öğrenme ortamı, eğitimde ailenin rolü, öğrenenin sorumlulukları gibi konular ele alınmıştır. Alanyazında İngilizce, Gürcüce ve Türkçenin öğretimi temelinde kültürlerarası farkındalık oluşturmada atasözlerinin rolünü ele alan bir doktora tezi (Gözpınar, 2014) belirlenmiştir. Türk ve İngiliz atasözlerini eğitsel değerler bakımından karşılaştıran başka bir araştırmaya rastlanmamıştır. Bu araştırmada ise eğitimle ilgili söylenmiş Türk ve İngiliz atasözleri belirlenmiş, içerdikleri eğitsel iletiler çözümlenerek iki ulusun eğitime bakış açıları arasındaki farklılıkların ve benzerliklerin ortaya konulması amaçlanmıştır. $\mathrm{Bu}$ amaç doğrultusunda aşağıdaki sorulara yanıt aranmıştır:

1. Türk ve İngiliz atasözlerinin içinde eğitimle doğrudan ya da dolaylı iletilere sahip olan başlıca atasözleri hangileridir?

2. İki ulusun atasözlerindeki iletiler eğitimin hangi boyutlarıyla ilişkilidir?

3. İki ulusun aynı konuyla ilgili olan atasözleri karşılaştırıldığında, eğitsel değerler açısından benzerlik ve farklılıkları nelerdir?

\section{Yöntem}

$\mathrm{Bu}$ araştırma betimsel bir nitelik taşımaktadır. Türk ve İngiliz atasözlerindeki eğitsel iletileri inceleyerek iki ulusun eğitsel değerlerini anlama ve karşılaştırma amaciyla gerçekleştirilmiştir. Bu amaca en uygun yöntemlerden biri olan doküman incelemesi kullanılmıştır. Araştırma, çalışma konusuyla ilgili içeriğin incelenmesine, çözümlenmesine ve yorumlanmasına dayanmaktadır.

\section{Araştırma Modeli}

Türk ve İngiliz atasözlerini, eğitsel iletiler açısından incelemenin amaçlandığı bu araştırma, yorumlamacı yaklaşımlardan olan doküman incelemesi deseniyle gerçekleştirilmiştir. Doküman incelemesi, araştırılması amaçlanan olgular hakkında bilgi içeren yazılı materyallerdeki içeriğin çözümlenmesini kapsar (Yıldırım ve Şimşek, 1999). Patton'a (çev. 2014) göre yorumbilimde, bazı şeylerin anlamının kültürel bağlam içinde ve özgün biçimde oluştuğu kabul edilir. Nitel araştırmada, dokümanların o kültürün yapısına ve onlara yüklenen anlamlara göre değerlendirilmesi önemlidir. Bir başka deyişle bu araştırma deseninde metnin içinde yer alan gerçeği ortaya çıkarmak amaçlanır. Deyimler, atasözleri, benzetmeler, anlatımlar vb. o kültürün yapısı içinde ele alınmalıdır (Sönmez ve Alacapınar, 2014).

$\mathrm{Bu}$ araştırmada; eğitim ile ilgili düşünceleri doğrudan ya da dolaylı olarak belirten Türk ve İngiliz atasözleri, içerdikleri eğitim anlayışları açısından incelenerek iki ulusa ait eğitim ile ilgili değerler belirlenmeye çalışılmıştır.

\section{Verilerin Toplanması}

Verilerin toplanmasında iki ulusun da atasözlerini kapsamlı olarak içerdiği kabul edilen ve araştırmacılar tarafından ulaşılabilen sözlükler kullanılmıştır. Eğitim ile ilgili Türk atasözleri belirlenirken Aksoy (1998), Oy (1972), Özdemir (1984) 
Püsküllüoğlu (2002); TDK (2009), TDK (2019) ve Yurtbaşı'dan (1993); İngiliz atasözleri belirlenirken de eski yıllardan beri kullanılan Smith (1936) ve kapsamlı bir içeriğe sahip olması nedeniyle de Speake ve Simson'dan (2008) yararlanılmıştır. Söz konusu sözlükler araştırmacılar tarafından taranarak eğitim ile ilgili iletilere sahip olan atasözleri belirlenmiştir. Daha sonra belirlenen atasözlerinin eğitim ile ilgili doğrudan ya da dolaylı iletisinin olup olmadığını belirlemek amacıyla eğitim bilimleri alanındaki üç öğretim üyesinden uzman görüşü alınmıştır. Uzmanların çoğunluğunun ya da tamamının eğitimle ilgili bir ileti içermediğini belirttikleri atasözleri araştırma kapsamından çıkarılmıştır. Verilerin çözümlenmesi geriye kalan atasözleri incelenerek yapılmıştır.

\section{Verilerin Çözümlenmesi}

Araştırmanın geçerliğini sağlamak için eğitimle ilgili atasözlerinin seçilmesi aşamasında uzman görüşüne başvurulmuştur. Veriler çözümlenirken öncelikle iki araştırmacının aynı veri kümesini kodlaması gerekmektedir. Araştırmacılar, başlangıçta karşılaştıkları güçlükleri tartıştıklarında, tanımlar daha çok açıklık kazanmaktadır (Miles ve Huberman, çev. 2015). Bu araştırmada da ön kodlamalar sonrasında araştırmacılar bir araya gelerek kodlamada dikkat edilmesi gereken konularla ilgili kararlar vermişlerdir. Daha sonra veriler iki araştırmacı tarafından ayrı ayrı yeniden kodlanmıştır. Kodlayıcılar arası güvenirliği hesaplamak için Miles ve Huberman (çev. 2015) tarafından geliştirilen, "kodlayıcılar arası güvenirlik=görüş birliği sayısı/toplam görüş birliği+görüş ayrılığg sayısı" formülü kullanılmıştır. Bu formüle göre kodlayıcılar arası güvenirlik $=54 /(54+5)=.92$ olarak hesaplanmıştır. Kodlama işlemi tamamlandıktan sonra kodlardan anlamca benzer ve ilişkili olanlar birleştirilerek altı tema oluşturulmuştur. Her bir tema kapsamında yer alan atasözleri, araştırma soruları bağlamında çözümlenmiş ve ilgili olduğu tema çerçevesinde tartışılmıştır.

\section{Bulgular}

Doğrudan ya da dolaylı bir şekilde eğitimle ilgili iletiye sahip; 31 Türk, 28 de İngiliz atasözü bulunmuştur. Bu atasözlerinin eğitsel konulara göre kategorik dağılımı Tablo 1'de verilmiştir.

Tablo 1

Türk ve İngiliz Atasözlerinin Eğitsel Alt Kategorilere Göre Dă̆llımı

\begin{tabular}{lrr}
\hline $\begin{array}{l}\text { Atasözlerindeki İletilerin İlgili Olduğu } \\
\text { Eğitsel Kategoriler }\end{array}$ & $\begin{array}{r}\text { Türk Atasözü } \\
\text { Sayısı }\end{array}$ & $\begin{array}{r}\text { Ingiliz Atasözü } \\
\text { Sayısı }\end{array}$ \\
\hline Çocukluk çağında eğitimin önemi ve niteliği & 6 & 4 \\
Akıl ve bilgi & 10 & 5 \\
Yaşamboyu öğrenme & - & 2 \\
Öğrenme ile güdülenme, hazırbulunuşluk, pekiştirme ve & 7 & 5 \\
ceza ilişkisi & 4 & 8 \\
İşbirliği, etkileşim ve model alma & 4 & 4 \\
Yaparak-yaşayarak öğrenme & 31 & 28 \\
Toplam &
\end{tabular}


Tablo 1'de de görüldüğü gibi, eğitim ile ilgili Türk ve İngiliz atasözleriyle ilgili altı tema bulunmaktadır. Atasözleri eğitsel konular bakımından zengin bir içeriğe sahiptir. Eğitimde çocuğun özelliklerine, bireysel farklılıklarına uygun bir eğitimle yetiştirilmesi birey olabilmesinin temel koşuludur. Yüzyıllardır söylenegelen ve eğitimin, çocuğun bu özelliğine uygun olmasını anlatan, "Ağaç yaş iken eğilir." (Aksoy, 1998, s. 119), "Çocuk insanın babasıdır." (Speake ve Simpson, 2008, s. 78) gibi atasözleri vardır. Eğitimin, akıl ve bilgi temelinde gelişeceği, "Cahile söz (laf) anlatmak, deveye hendek atlatmaktan güçtür." (Aksoy, 1998, s. 210) atasözüyle anlatılır. Ayrıca eğitimin yaşamboyu devam eden bir süreç olduğunu, öğrenme ile güdülenme, hazırbulunuşluk, öğrenilenlerin pekiştirilmesi, yeri geldiğinde cezaya başvurulmasının gerektiğini belirten atasözleri de bulunmaktadır. İçinde bulunduğumuz yüzyılda eğitimde işbirliği, etkileşim, model alma ve yaparakyaşayarak öğrenme önem kazanmıştır. Bunları anlatan atasözleri eğitsel değerler içermektedir. Türk ve İngiliz atasözleri eğitsel iletilerinin konularına göre aşağıdaki temalar altında karşılaştırmalı olarak incelenmiştir.

\section{Çocukluk Çağında Eğitimin Önemi ve Niteliği}

İnsan yaşamında çocukluk döneminin önemi büyüktür. Bu dönemde bir yandan kişiliğin temelleri atılırken diğer yandan birçok özellik bakımından hızlı bir gelişim ve yoğun öğrenmeler yaşanır. Gelişimle ilgili birçok kurama göre; bu süreçteki belirsizlikler nedeniyle ikilemler, uyum sorunları ve bazı çatışmalar ortaya çıkar. Çocuğun bunları başarıyla atlatması çevreyle kurduğu sağlıklı ve doyurucu ilişkiye bağlıdır. Bu nedenle eğitimciler, psikologlar ve hatta birçok anne-baba çocuklukta ailede başlayıp çevre ve okulda devam eden eğitimin, çocuğun doğasına uygun ve onun benlik algısını geliştirici olması konusunda görüş birliği içindedirler. $\mathrm{Bu}$ düşüncenin köklerini, uzun yıllar boyunca söylenerek günümüze kadar gelmiş olan atasözlerinde de bulmak olanaklıdır. Türk ve İngiliz atasözlerinde çocukluk eğitiminin önemini doğrudan ya da dolaylı olarak benzetmeler ve mecazlarla anlatan örnekler vardır.

Bir İngiliz atasözünde, "Çocuk insanın (bireyin) babasıdır." (The child is father of the man) (Speake ve Simpson, 2008, s. 78) denilerek kişiliğin temellerinin çocukluk döneminde atıldığı; dolayısıyla bu dönemde verilen eğitimin çocuğun kişiliğinin biçimlenmesinde belirleyici olduğu vurgulanmıştır. Çocuğun çeşitli davranışları kazanmasında önemli dönemler vardır. Davranışın kazanılabilmesi için ilgili olduğu dönemin koşullarına uygun ortam hazırlanması gerekir. Öğrenenler tarafından ilgili yaşantıların zamanında geçirilmemesi, davranışın kazanılmasını güçleştirir. Dolayısıyla verilen eğitimin bir yandan çocuğun içinde bulunduğu gelişim döneminin özelliklerine uygun olmasına diğer yandan davranışın kazanılması koşullarının oluşmasına dikkat etmek gerekir. Söz konusu gerekliliği; "Ağaç yaşken eğilir." (Aksoy, 1998, s. 119) ve "Demir tavında dövülür." (Özdemir, 1984, s. 70) şeklinde belirten iki Türk atasözü vardır. Başka bir İngiliz atasözünde de "Yaşlı köpeğe yeni hileler ögretemezsin." (You can't teach an old dog new tricks.) (Speake ve Simpson, 2008, s. 474) ve bir Türk atasözünde de "İnsan yedisinde ne ise yetmişinde de odur." 
(Aksoy, 1998, s. 328) denilerek insanın gelişiminde çocukluk döneminin önemi vurgulanır.

Atasözlerinde dile getirilen bu düşünceler bilimsel araştırmalara konu olmuş; sistemleştirilerek bilimsel bilgi niteliği kazanmıştır. Günümüz eğitiminde çocuğun bilişsel, duyuşsal, devinişsel öğrenmelerinin odağında atasözlerinde de belirtilen zamanlama kavramı vardır. Çocuk belli gelişim dönemlerinde ve yaşlarda belli tür öğrenmelere karşı yüksek duyarlık gösterme eğilimindedir (Senemoğlu, 2013). Eğitimin başarılı sonuçlar vermesi için söz konusu eğilimlerin dikkate alınması ve gelişim ile öğrenme arasında eşgüdüm sağlanması gerekir. Dolayısıyla çocuğa belli bir davranışın o davranış için uygun olan dönemde öğretmeye çalışılmasına ve bunu yaparken de o dönemin özelliklerinin göz önünde bulundurulmasına ihtiyaç vardır (Kurt, 1997).

Eğitimde çocuğun içinde bulunduğu dönemin özelliklerini dikkate almak kadar ona zamanı doğru kullanma özelliği kazandırmak da önemlidir. Çünkü zamanı etkili kullanma özelliği kazanamamış bireylerde geçerli bir neden olmaksızın, yapmaları gereken görevleri erteleme eğilimi sık rastlanan bir durumdur. İşleri erteleme eğilimi beraberinde bilgi eksikliği, düzensizlik, eşgüdüm güçlüğü gibi sorunlar getirmektedir. Araştırmalar zaman yönetiminin etkisiz olması ile bireyin yaşadığı eşgüdüm güçlüğü arasında pozitif bir ilişki olduğunu göstermektedir (Balkıs, Duru, Buluş ve Duru, 2006; Kızılkaya-Cumaoğlu ve Diker-Çoşkun, 2012).

İki ulusun atasözlerinde de zamanı doğru ve etkili kullanmanın insana özgü önemli bir kişilik özelliği olduğu belirtilmektedir. İnsanların bu özelliğe sahip olmasının önemini açıklayan söz konusu atasözleri anlam bakımından eğitimle ilgili süreçleri de kapsamaktadır. Planlı ve düzenli çalışma, bir kişilik özelliği olarak hem genel yaşamı hem de eğitsel süreçlerdeki davranışları etkilemektedir. Ayrıca planlı ve düzenli çalışma alışkanlı̆̆ı kazandırmak eğitimin önemli hedeflerinden biridir. Dolayısıyla aile ve okuldaki eğitimde çocuklara zamanı etkili kullanmanın önemini sezdirmek, örnek olmak ve onların bu konuda gösterdikleri olumlu davranışları pekiştirmek gerekmektedir.

Zamanı doğru yönetme düşüncesi İngiliz atasözlerinde; "Dakiklik, prenslere özgü bir kibarlıktır." (Punctuality is the politeness of princes) (Speake ve Simpson, 2008, s. 393) şeklinde belirtilirken yapılacak işleri savsaklama ise; "Erteleme, zaman hırsızlığıdır." (Procrastination is the thief of time) (Smith, 1936, s. 363) biçiminde kullanılmaktadır. $\mathrm{Bu}$ örneklerin birincisinde, zamanı etkili kullanmanın soyluluk göstergesi olduğu belirtilirken ikincisinde, yapılacak işleri erteleme, yani zamanı yanlış kullanma hırsızlığa benzetilmektedir. Türk atasözlerinde de "Bugünkü işini yarına bırakma." (Özdemir, 1984, s. 55) ve "Vakit, nakittir." (Aksoy, 1998, s. 458) biçiminde belirtilen benzer örnekler bulunmaktadır. Bu örneklerden birincisinde; işi zamanında yapmanın önemi belirtilirken ikincisinde zamanın değerli olduğuna ve boşa harcanmaması gerektiğine dikkat çekilmektedir. 
Çocuğun eğlenirken öğrendiği ortamlardan biri de oyundur. Oyun, çocuğun hayallerini, beklentilerini, üzüntülerini ve yeteneklerini yaşama aktardığı bir laboratuvar gibidir. Çocuk büyüdükçe oyunları da daha sosyal içerik kazanır. Daha önceleri oyun sırasında benmerkezci bir tutum sergilerken artık diğer çocuklarla ilgilenmeye ve onlara güvenmeye başlar (Charles, çev. 2003). Oyunun bir başka özelliği, çocuğun oyunlarında hayal dünyasından yararlanmasıdır. Ancak oyunda işlediği konular yaşamın gerçekleri üzerine kurulmuştur. Bu özelliğinden dolayı oyun, hayal dünyası ile gerçekler dünyasını birleştiren bir köprü gibidir. Çocuk, oyun sırasında geçirdiği doğal yaşantılar sayesinde algısını, yeteneklerini ve kendine güven duygusunu geliştirir; bilmediklerini bilinir; görmediklerini görünür hale getirir. Zaman zaman mantık bağlantılarını bir kenara bırakarak seslerden, sözlerden ya da çizgilerden kurulu birleşimler yapar. Böylece oyun, çocuk için bir yaratma ortamı haline gelir. Kısaca oyun, çocuğun gelişmesi ve kişilik kazanması için sevgiden sonra gelen ikinci en önemli ruhsal besindir (Yörükoğlu, 2006).

Türkçede kişilik gelişiminde oyunun önemini anlatan; "Tay iken oynamayan, at olamaz." (TDK, 2009, s. 193) diye bir atasözü vardır. Bu atasözü değiş̧meceli bir anlam içermekte ve atın yetişmesi ile çocuğun bağımsız kişilik geliştirmesi arasında benzerlik kurmaktadır. Yetişkinlere göre çocuğun eğlence için kullandığı bir ortam olan oyun; aslında eğlencenin yanı sıra çocuğun türlü deneyimler yaşadığı, bunlardan kendine göre sonuçlar çıkardığı ve kendi gerçekliğini dışa vurduğu bir araçtır.

Oyun, çocuğun yaşamı deneyimlediği ve sorun çözme becerileri kazandığı en önemli ortamlardan biridir. Örneğin, Eric Ericsson'un psiko-sosyal gelişim kuramına göre çocuğun yaşadığı, utanma ve kuşku ile özerklik; girişkenlik ile suçluluk; başarı ile aşağılanmışlık (Yazgan-İnanç, Bilgin ve Kılıç-Atıcı, 2007) ikilemlerini sağlıklı bir şekilde atlatarak olumlu benlik algısı oluşturmasında oyun etkili bir yaşantı biçimi olabilir. Böyle bir süreçte çocuğun bağımsızlık, özerklik ve özgüven duyguları; gerçekçi seçimler yapabilme özellikleri ve girişkenliği gelişebilir.

\section{Akıl ve Bilgi}

Türk ve İngiliz atasözlerinde eğitimin temel aracı ve ortamı olan akıl ve bilgi konusunda da çok sayıda atasözü bulunmaktadır. Bilgi sorunu, bilimin anası olarak kabul edilen felsefenin de en temel konularından biridir. İnsanoğlu, çok eski çağlardan beri bilginin kaynağını ve gerçek bilginin ne olduğu ve nasıl elde edileceğinin arayışı içinde olmuştur. Bilgi, eğitim sürecinin de önemli bir ögesidir. Kazanılan her bilgi, o konuda gerçekleştirilecek yeni yaşantılarla yeni bilgilerin yapılandırılmasına ve yaşamın kolaylaşmasına hizmet eder. Eğitim; bireye bilgi, beceri ve tutumlar kazandırarak bireyi ve onun içinde bulunduğu toplumu derinden etkiler. Bilgiye ve bilime önem veren toplumlar gelişirken bunları önemsemeyen toplumlar gelişmiş olanlara bağımlı duruma gelir.

Bilgi sahibi olmanın güçlü olmakla eşdeğer olduğu ve insanların sahip olabilecekleri en değerli varlığın akıl olduğu atasözlerinde değişik benzetmelerle anlatılmıştır. Akıl; düşünme, anlama ve kavrama gücü, salık verilen yol, bellek gibi 
anlamlarda kullanılmaktadır (TDK, 2011). Birey, bu güce sahip olmadan öğrenmede ve öğrendiklerini kullanmada güçlükler yaşar. Dolayısıyla akıl, bilmenin ve bildiklerini düzenlemenin ve böylece yaşamını verimli bir biçimde sürdürmenin anahtarıdır. Bu nedenle kültürümüzde; “Akıl kişiye sermayedir.” (Oy, 1972, s. 251). “Akıl para ile satılmaz.” (Püsküllüoğlu, 2002, s. 20), “Akıllı oğlan neyler ata malını; akılsız oğlan neyler ata malını.” (Aksoy, 1998, s. 129) gibi atasözleri vardır. İngiliz kültüründe de "Ak1llı olmadan servetin değeri yoktur." (Without wisdom wealth is worthless) (Smith, 1936, s. 594) olarak kullanılan atasözlerinde; aklın paradan da önce gelen bir anamal ve her türlü kazancın asıl kaynağı olduğu belirtilmiştir (Özdemir, 1984). Her ne kadar Türk atasözlerinde; “Akıllı köprüyü arayıncaya dek deli suyu geçer.” (Aksoy, 1998, s. 129) şeklinde belirtilen düşünce yukarıda belirtilen yargıya aykırı düşüyor gibi görünse de aklın önemi olmadığını belirtmekten çok herhangi bir konuda kararsız kalmanın olumsuz sonuçlarına dikkat çekmek için kullanılır.

Atasözlerimiz içinde yer alan; "Cahile söz (laf) anlatmak, deveye hendek atlatmaktan güçtür," (Aksoy, 1998, s. 210) atasözüyle aklın zihni, bireyi idare edici güç olduğu, cahil ve bilgisiz kimseleri eğitmenin en zor işlerden daha güç olduğu anlatilır.

Bilgi de insan için önemli bir değerdir. İnsan, eğitsel bir yaşantı geçirirken önceden edindiği bir birikimi kullanır. Dolayısıyla kazanacağı yeni bilgiler geçmişte kazanmış olduğu bilgilere dayalı, gelecekte edineceği bilgilere de hazırlayıcı niteliktedir. $\mathrm{Bu}$ nedenle geçmişte kazanılan bilgiler, gelecekteki öğreneceklerinde belirleyici olmaktadır. Bu durum bir İngiliz atasözünde, "Başarı başarıyı getirir." (Nothing succeeds like success.) (Smith, 1936, s. 331) biçiminde belirtilmektedir. Başarının sürekliliğini sağlamak için kazanılan bilginin kalıcı olması da önemlidir. Dolayısıyla bilginin kayıt altına alınması gerekir. Türk atasözleri içinde yer alan, “Âlim unutmuş, kalem unutmamış.” (Aksoy, 1998, s. 137) atasözü de insanın ne kadar iyi bilirse bilsin her şeyi aklında tutamayacağını, bu nedenle bildiklerini yazıya aktarmasının gerekliliğini anlatır. "Kalem kılıçtan keskindir." (The pen is mightier than the sword.) (Speake ve Simpson, 2008, s. 374) olarak kullanılan Ingiliz atasözünde de yazının gücü ve kalıcılığı belirtilir.

Cahillikten kurtulma, bilgi kazanma ile olanaklı olur. Bilgi kazanmanın ve bilimle uğraşmanın birey ve toplum açısından önemini anlatan çok sayıda atasözü bulunmaktadır. Örneğin İngiliz atasözleri arasında, "Bilgi güçtür." (Knowledge is power.) (Speake ve Simpson, 2008, s. 265) ifadesiyle bilginin önemi belirtilmektedir. Bu konudaki bir Türk atasözünde de "Bilmemek ayıp değil, sormamak (öğrenmemek) ayıptır.” (Aksoy, 1998, s. 189) denilerek insanın her şeyi bilmesinin olanaksız olduğu, dolayısıyla bunun kusur olarak kabul edilemeyeceği, ancak insanın bu bilgiye gereksinimi olmasına karşın öğrenmeye çalışmamasının ayıp olarak kabul edileceği anlatılmaktadır. Başka bir Türk atasözünde ise; "Bin bilsen de, bir bilene danış." (Aksoy, 1998, s. 189) tümcesiyle insanın algılarının onu yanıltabileceği, dolayısıyla farklı düşüncelere açık olmanın önemine dikkat çekilmektedir. "Akıl akıldan üstündür." (Özdemir, 1984, s. 17) atasözünde ise; insanın bildiklerinin belli sınırları 
olduğu, o konuyu daha iyi bilen insanların düşüncelerini alarak karar vermesinin yararlı olacağı dile getirilmektedir. Bu konuyla ilgili olarak söylenmiş başka bir İngiliz atasözündeki, "Azıcık bilgi (öğrenme) çok tehlikeli bir şeydir." (A little learning is a dangerous thing.) (Smith, 1936, s. 17) ile bir Türk atasözündeki, "Yarım hekim candan eder, yarım hoca dinden eder." (Özdemir, 1984, s. 195) tümcesi, yeterli bilgiye sahip olunmadan verilecek kararların ve yapılacak işlerin tehlikeli ve yaşamsal sonuçları olabileceğini belirtmektedir.

\section{Yaşamboyu Öğrenme}

İnsanı diğer varlıklardan ayıran düşünme ve öğrenme gücü, belli bir mekân ile sınırlı olmaksızın doğumdan ölüme kadar devam eder. Hiç kuşkusuz öğrenme hızı çocuklukta daha yüksektir. Ama bu süreç çocukluktaki kadar olmasa da yaşamboyu devam eder. Bu nedenle yaşamboyu öğrenme kavramı, öğrenmeyi yaşamın belli bir dönemine ait olmaktan çıkarıp tüm yaşama yayan bir anlayışı yansıtır. Buna göre birey; kişilik, sosyal ve mesleki anlamda doğal ve sürekli devam edecek şekilde gelişimini sürdürür (Koç, 2005).

Yaşamboyu öğrenme düşüncesi 1950'lerden sonra yaygınlaşmış ve özellikle de 1960 yılında Montreal'de yapılan Uluslararası Yetişkin Eğitimi Konferansı'nda, eğitimin yaşamboyu devam etmesi gerektiği belirtilmiştir (Erdamar, 2011). 1972'de Birleşmiş Milletler Eğitim, Bilim ve Kültür Örgütü (UNESCO) eğitimin geliştirilmesi komisyonunda eğitimi, okul yaşı ve okul binalarıyla sınırlandırmanın doğru olamayacağına karar verilmiştir. Bu bağlamda eğitimin okulu ve okul dışındaki tüm yaşamı kapsaması; eğitsel etkinliklerin esnek olması ve eğitimin yaşamboyu devam eden varoluşsal bir süreç olarak anlaşılması gerektiği gibi ilkeler belirlenmiştir (Knowles, 1996). Böylece, yaşamboyu öğrenme sistematik hale getirilmiştir. Ancak yaşamboyu öğrenme düşüncesinin köklerinin çok eskilere dayandığını, ulusların atasözlerindeki örneklere bakarak söylemek mümkündür. İngiliz atasözleri içinde, "Öğrenmek için asla geç değildir." (It's never too late to learn.) (Speake ve Simpson, 2008, s. 341); "Öğrenemeyecek kadar yaşlanamazsın." (Never too old to learn.) (Speake ve Simpson 2008, s. 274) gibi örnekler, öğrenmenin insan yaşadıkça devam edeceğini belirtmektedir.

Yaşamboyu öğrenme konusundaki yukarıda verilen olumlu örneklere karşın, İngiliz atasözlerinde yer alan "Yaşlı köpeğe yeni hileler öğretemezsin." (You can't teach an old dog new tricks.) (Speake ve Simpson, 2008, s. 474) ve Türk atasözleri içinde yer alan "İnsan yedisinde ne ise yetmişinde de odur." (Aksoy, 1998, s. 328) atasözlerinde ilk bakışta yaşamboyu öğrenme anlayışına karşı çıkılıyor gibi görünmektedir. Fakat ilk atasözünde, bazı becerilerin yaşa bağlı olarak öğrenilmesinin daha güç olacağı; ikincisinde de çocuklukta edinilmeye başlanan kişilik özelliklerinin daha sonra değiştirilmesinin zor olacağını belirtmek için söylendiği; dolayısıyla her iki atasözünün yaşamboyu öğrenme düşüncesine karşı olma gibi bir anlam içermediği söylenebilir. 
Yukarıdaki örneklerden de anlaşılacağı gibi İngiliz atasözlerinde yaşamboyu öğrenme ile ilgili düşüncelere yer verilirken incelenen Türk atasözleri ile ilgili kaynaklarda bu konuyla ilgi söylenmiş atasözlerine rastlanmamıştır. Bu durum, Türk kültüründe çocukluk ve gençlikte öğrenilenlerin yeterli kabul edilmesi ve dolayısıyla yaşamboyu öğrenmenin öneminin yeterince fark edilememiş olmasıyla açılanabilir.

\section{Öğrenme ile Güdülenme, Hazırbulunuşluk, Pekiştirme ve Ceza İlişkisi}

Öğrenmeyi etkileyen pek çok etken vardır. Bunlardan bir bölümü öğreneni öğrenmeye hazır hale getirme için, bir bölümü de öğrenilenlerin kalıcılığını sağlamak için kullanılır. Kalıtsal özellikler ile öğrenmenin etkileşiminin bir ürünü olan hazırbulunuşluk olmadan öğrenme zordur. Hazırbulunuşluğa, öğrenenin entelektüel geçmişi, geçirdiği yaşantılar ve öğretim yöntemlerinin önemli etkisi vardır (Fidan, 1986). Bir konudaki öğrenmeler bireyi o konuyla ilgili daha sonraki öğrenmelere hazırlar. İngiliz atasözleri içinde bilişsel hazırbulunuşluğun önemini anlatan "Başarı başarıyı getirir." (Nothing succeeds like success.) (Speake ve Simpson, 2008, s. 353) biçiminde bir atasözü vardır. Türk atasözleri içinde yer alan "Aşk olmayınca, meşk olmaz.” (Aksoy, 1998, s. 157) atasözünde de öğrenmeye duyuşsal hazırbulunuşluğun ve bireyi harekete geçirecek bir neden olmasının önemi anlatılır. Meşk sözcüğü TDK'ya (2011, s. 1641) göre “Bir öğretmenin, aynısını yazmaları için öğrencilerine verdiği yazı örneği. Yazı veya müzikte alışmak ve öğrenmek için yapılan çalışma, el alıştırması" biçiminde tanımlanmıştır.

Öğrenmeyi etkileyen bir başka etken de güdülenmedir. "Güdülenme, içsel isteklerin ya da dışsal olayların belirlediği gereksinimi gidererek hedefe ulaşabilmesi için organizmanın davranıma hazır hale gelmesidir" (Bakırcıŏlu, 2012, s. 406). Güdülenme, bireyin başarı ihtiyacından ve kontrol odağından etkilenebilir (Driscoll, çev. 2012). Kişiyi bir davranışı yapmaya isteklendirici etkenler olmadan o davranışı yapmaya yöneltecek süreçler bireyde beklenen etkiyi yaratamaz. Güdülenmiş olma kişiyi belli biçimde davranmaya yöneltmenin yanı sıra davranışı kararlılıkla, istekle ve ısrarla yapmasını sağlar (Fidan, 1986). Güdüler, kaynağına, süreç ve içeriğinin dayandığı temellere, güdülenmeyi sağlayan etkenin tekil ya da çoğul olmasına vb. özelliklere göre farkl1lık gösterebilmektedir (Seker, 2015).

Maslow, bireyin gereksinimleri içinde önceliği yaşamla ilgili temel gereksinimlere vererek sıradizinsel (hiyerarşik) bir düzende belirtir. Bu sıralamada; temeli fizyolojik olmak üzere, güvenlik, sosyal, değer verilme-saygınlık ve kendini gerçekleştirme gereksinimleri vardır (Maslow, 1954). Bu gereksinimler aynı zamanda birer güdü kaynağıdır. Bireyi, gereksinimini karşılayabilmesi için belli biçimlerde davranmaya yöneltir.

İnsanları öğrenmeye yönelten etkenlerden biri de merak ve dolayısıyla bilme gereksinimidir. Merak, çocukları ve yetişkinleri öğrenmeye güdüleyen etkendir (Driscoll, çev. 2012). Bireyin zihninde oluşan belirsizlikler, merak etmesini, durumu ya da olayı anlama çabası içine girmesini ve bu amaçla yaşantılar geçirmesini sağlar. Bireyin zihnindeki belirsizlikler, düşünmesini, sorgulamasını ve dolayısıyla 
öğrenmesini olumlu olarak etkiler. İnsan, merak güdüsüyle dünyaya gelir. İçinde bulunduğu dünyayı tanımaya çalışan çocuk, çok meraklıdır ve bu amaçla etkinlikte bulunur fakat aynı etkinliği uzun süre devam ettiremez. İçinde bulunduğu bu durum onu sürekli olarak konu ve etkinlik değiştirmeye, yeni şeyler merak etmeye yöneltir (Yapıcı ve Yapıc1, 2005). Merakını gidermek amacıyla yaptıkları onu birtakım sonuçlara götürür; böylece öğrenme gerçekleşmiş olur. Ne var ki bireyin öğrendikleri pekiştirilirse kalıcı duruma gelir. Davranışçı kuramcılar, öğrenmede uyaran tepki ilişkisinin, davranışın ortaya çıkarılmasındaki önemine değinirken davranışın pekiştirilmesinin de bu bağın kurulması kadar önemli olduğunu belirtirler. Pekiştirme, olumlu ya da olumsuz olmak üzere iki şekilde yapılır. Ödül gibi olumlu uyarıcılar ile pekiştirilen davranışlar ve olumsuz uyarıcıların ortamdan kaldırılması ile olumsuz bir şekilde pekiştirilen davranışların tekrarlanma olasılığı, olumlu ya da olumsuz cezalandırma sonucunda ortaya çıkan davranışların tekrarlanma olasılığından daha yüksektir (McCarthy, Baker, Minami ve Yeh, 2011).

Edimsel koşullanmada davranışın yapılması eğilimini, edimin sonucunda yaşanan deneyim belirler. Söz konusu deneyim, davranışı yapan birey açısından olumlu ise, ilk deneyimindekine benzer bir doyumu elde edebilmek için davranışı daha sıklıkla yapmaya koşullanır. Sonuç olumsuz ise davranışı yapma olasıllı̆̆ zayıflar. Türk atasözleri içinde bu durumu anlatan "Marifet iltifata tabidir." (TDK 2019) diye bir örnek vardır. Bireyin yaptığı bir iş beğenilir, takdir edilirse onun doğasında olan beğenilme ve takdir edilme ihtiyacı karşılanmış olur. Beğenilme ihtiyacı karşılanan bireyin yaşadığı olumlu deneyim, benzer etkinliklerde bulunma eğilimini güçlendirir. İngiliz atasözleri içinde "İhtiyaç icadın anasıdır." (Necessity is the mother of invention.) (Speake ve Simpson, 2008, s. 338) şeklinde bir atasözü vardır. Başlangıçta bireyin bir ihtiyacını karşılamak amacıyla yaptığı bir edim pekiştirildiğinde, onun yeni ve yaratıı deneyimler yaşama eğilimi güçlenmiş olur.

Alışılagelmiş yollar kullanarak yeni ve orijinal keşifler yapılamaz. Dolayısıyla bireyin yaşantıya açık olması ve icat yapabilmek için yaratıcı bir süreci yaşaması gerekir. Yaratıcılık yeni deneyimlere açık olma, olgu ve olaylara çok yönlü bakabilme, kalıpların dışına çıkabilme ve merak etme gibi özellikler gerektirir. Merak, önemli olmasına karşın tek başına yeterli değildir. İnsanın merakını gidermek için sabırlı olması, merakı besleyecek ortamlar, yaşantılar ve bazı riskleri göze alması da gerekir. Sabırlı olmanın önemini anlatan bir İngiliz atasözünde "Sabır bir meziyettir." (Patience is a virtue.) (Smith, 1936, s. 354) denilirken aynı konuyla ilgili olarak söylenmiş bir Türk atasözünde de "Sabır acıdır, meyvesi tatlıdır." (Aksoy, 1998, s. 418) denilerek her işte olduğu gibi, eğitimde de sabretmenin zor fakat sonucunun güzel olacağına dikkat çekilmektedir.

Öğrenirken sabırlı olma kadar yeni deneyimlere açık olma ve bu amaçla risk alma da önemlidir. Bir İngiliz atasözünde bu durum "Yumurtaları kırmadan omlet yapamazsin." (You can't make an omelette without breaking eggs.) (Speake ve Simpson, 2008, s. 360) biçiminde açıklanırken işin gereğine uygun davranmanın önemi vurgulanır. Bir Türk atasözünde de bu durum "Sirkesini, sarımsağını sayan 
paçayı yiyemez." (Aksoy, 1998, s. 428) diye anlatılır. Atasözlerimiz içinde merakın kendi içinde bir takım riskler barındırdığını anlatan örnekler de vardır. "Merak insanı mezara sokar.” (TDK, 2019) biçiminde kullanılan Türk atasözünde her şeyi öğrenme isteğinin, insanı birtakım tehlikelerle karşı karşıya getirebileceği belirtilerek tehlikelerden kaçınmak için ilgili davranışı yapmaktan vazgeçmesi salık verilir. Oysa insanın yaratıcı olabilmesi ve öğrenmesi için risk alması gerekir. Bu nedenle yukarıda verilen atasözünün insanlar arasında yaygın olan rahatına düşkünlük düşüncesini yansıttığı görülmektedir.

Türk ve İngiliz atasözleri içinde cezayı, özellikle de dayağı, davranışı düzeltmenin bir gereği olarak öneren örnekler bulunmaktadır. Türk atasözlerinde cezalandırma ile ilgili olarak iki atasözünü örnek verebiliriz: "Dayak cennetten çıkmıştır." (Aksoy, 1998, s. 229), "Kızını dövmeyen dizini döver.” (Aksoy, 1998, s. 362). İngiliz atasözlerinde de "Sopayı sakla çocuğu şımart." (Spare the rod and spoil the child.) (Smith, 1936 s. 401) şeklinde bir atasözü bulunmaktadır. Günümüzde dayağın düzeltici bir işlevi bulunduğuna ilişkin yargı, iki toplumda da genel olarak kabul görmese de eskiden yukarıdaki atasözlerinin belirttiği gibi; cezalandırmanın, olumsuz davranışları düzeltici olarak görülmesinden dolayı eğitimde kullanılmasının doğru bir yaklaşım olarak görüldüğü anlaşılmaktadır.

Eski toplumlarda (günümüzde çok azalmış olsa da) ceza, hatalı ya da yanlış davranışları düzeltmenin aracı olarak kullanılmıştır. İnsanlar bazen olumsuz davranışlar da edinebilirler. Bu tür davranışları ortadan kaldırmak için kullanılan araçlardan biri cezalandırmadır. Davranışçı kuramcılara göre cezanın bireyi istenmeyen davranıştan kısa süreliğine vazgeçirme gibi bir etkisi olabilir. Bir başka deyişle ceza, ilgili olduğu davranışı o an için durdurabilir fakat bu durum davranışın ortadan kalktığı ya da unutulduğu anlamına gelmez (Driscoll, çev. 2012). Bir başka deyişle ceza verildiği sürece davranışı bastırmakta, ortadan kaldırıldığında söz konusu davranış tekrar ortaya çıkmaktadır. Davranışçı kuramların da gösterdiği gibi dayak, yanlış davranışları ortadan kaldırmaya yönelik bir araç olma özelliği taşımamaktadır. Dolayısıyla günümüzde dayağın davranışı düzeltici bir işleve sahip olduğuna ilişkin atasözleri de geçerliğini yitirmeye başlamıştır.

\section{İşbirliği, Etkileşim ve Model Alma}

Eğitim, etkileşimli bir süreçtir. Toplumsal bir varlık olan insan, diğer insanlarla iletişim ve etkileşim kurmak zorundadır. Bu etkileşimlere bağlı olarak başkalarından öğrenir, başkalarına öğretir ve bu süreçte zaman zaman da diğer bireylerle işbirliği yapar. $\mathrm{Bu}$ özelliğinden dolayı eğitimin kişilerarası ilişkilere dayalı olma gibi bir özelliği vardır. Çünkü birey her şeyi bilemez; bilmedikleri, çözemedikleriyle ilgili olarak diğer bireylerle işbirliği yapma ve böylece kendi eksikliklerini giderme gereksinimi duyar; bazen de bildiklerini paylaşarak diğer bireyleri etkileme, yönlendirme, inandırma gibi çabalarda bulunur. Başkalarıyla kurulan etkileşimler bireyin tek başına üstesinden gelemeyeceği sorunları çözebilmesini sağlar. Türkçedeki "Bir elin nesi var, iki elin sesi var." (Özdemir, 1984, s. 49), "Birlikten kuvvet doğar." (TDK, 2019) atasözleri toplumsal anlamda olduğu kadar eğitimde de 
işbirliğinin önemli olduğunu belirtir. "Az eli aşta gör, çok eli işte gör." (Aksoy, 1998, s. 170) atasözü ile de yemeğin az kişiyle yenildiğinde insanların doyabileceği, bunun dışında kalan işlerin ise çok kişiyle kısa sürede yapılabileceği belirtilerek işbirliğinin sağlayacağı gücün zor işleri başarmayı kolaylaştıracağı vurgulanmıştır. Bu kural eğitim için de geçerlidir.

Günümüz eğitiminde işbirlikli öğrenme, öğrencilerin küçük gruplar halinde çalışarak ve birbirlerinin öğrenmesine yardım ederek öğrenmeyi gerçekleştirdikleri süreç olarak kabul edilmektedir. İşbirliği için bazı koşulların olmasına gereksinim bulunmaktadır. Bunlar; grup ödülü, olumlu bağımlılık, bireysel değerlendirilebilirlik, yüz yüze etkileşim, sosyal beceriler, grup sürecinin değerlendirilmesi ve eşit başarı firsatıdır (Ün-Açıkgöz, 2005). İşbirlikli öğrenmede bu koşulların yerine getirilmesinden sonra grupta yer alan öğrenciler hem kendilerinin hem de gruptaki arkadaşlarının başarısı için çaba gösterirler. Başarı ya da başarısızlık bireysel olduğu kadar gruba da aittir. Dolayısıyla öğrencilerin tek tek başarılı olması yeterli görülmez. Bütün öğrencilerin başarılı olması istenir. Bu özelliğinden dolayı işbirlikli öğrenme süreci öğrencilere; arkadaşlarının düşüncelerinden yararlanma, hatalarını görme ve bunları düzeltebilme, yeni farklı düşüncelere açık olma, olaylara çok yönlü bakabilme gibi özellikler kazandırır.

Yukarıdaki atasözleri, doğrudan eğitimle ilgili bir düşünceyi belirtmek için söylenmiş olmasa da eğitim uygulamalarını da ilgilendirmekte, eğitsel bir ileti de içermektedir. Başkalarının bilgi ve deneyimlerinden yararlanma, birlikte çalışıp başarıyı yükseltme, değişik düşüncelere açık olarak gelişmeyi sağlama günümüzde kabul edilen eğitim değerleri arasındadır. Bu anlayıș, bireysel öğrenmeyi olduğu kadar işbirlikli öğrenmeyi de önemli duruma getirmiştir. Böylece bireyin tek başına üstesinden gelemeyeceği sorunların bireylerin birbirlerinin eksikliklerini tamamlamalarıyla çözülebileceği kabul edilmektedir.

İnsanlar, diğer insanları gözlemleyerek de öğrenirler. Sosyal öğrenme kuramcıları, gözlem sonucunda edinilen davranışın basit bir taklitten ibaret olmadığını belirtir. Gözlemci, gözlemi yaparak bilgilenir ve bir takım sonuçlar çıkarır. Çıkardığı sonuçları kendisi için yararlı olan durumlarda uygulamaya koyar (Bayrakçı, 2007). Kimi zaman da insanların öğrendikleri o an ortaya çıkmaz fakat ilerleyen zamanlarda davranış değişikliğine neden olabilir (Gültekin, 2019). Vygotsky, kişisel gelişimin, çocuğun içinde yer aldığ sosyal ortam göz önünde bulundurulmadan anlaşılamayacağını belirtirken (Tuge ve Ragoff, 1989 akt. Driscoll, çev. 2012) bu etkileşimlere dikkat çekmektedir. Türkçede, etkileşim sonucunda bireyde oluşan davranış değişmelerini anlatan çok sayıda atasözü vardır: "Kır atın yanında duran, ya huyundan ya suyundan." (Özdemir, 1984, s. 131) atasözü, kişinin arkadaşlık ettiği kişiden etkileneceğini; "Körle yatan, şaşı kalkar." (Aksoy, 1998, s. 374) atasözünde ise, değersiz ve kötü kişilerle arkadaşlık edenlerin kötü alışkanlıklar kazanacağını belirtmektedir. "Çürük elma yanındakileri de bozar." (The rotten apple injures its neighbour) (Speake ve Simpson, 2008, s. 412) şeklindeki İngiliz atasözü ile benzer bir düşünceyi anlatmak için Türkçede kullanılan "Üzüm üzüme baka baka kararır." 
(Aksoy, 1998, s. 457) atasözü ile bir arada bulunan ve arkadaşlık eden kişilerin birbirlerine bazı kötü huylar aşılayabileceği belirtilerek etkileşimin ve etkileşimde bulunulan insanların niteliklerinin önemi vurgulanır. Başka bir İngiliz atasözü ise; "Kişi arkadaşıyla bilinir." (A man is known by the company he keeps.) (Speake ve Simpson, 2008, s. 88) şeklindedir. Bu atasözü ile de arkadaşlık yapan insanların etkileşim içinde birbirlerine benzer özellikler kazanacakları ve dolayısıyla benzer davranışlar sergileyecekleri belirtilir.

İnsanlar arasındaki sosyal ilişkilere bağlı olarak model alma ve modelin davranışlarını taklit ederek ya da o davranışları kendi amaçlarına göre uyarlayarak yeni davranışlar oluşturma da söz konusu olabilmektedir. Modelin davranışlarının içselleştirilmesinde gözlemcinin ve modelin özellikleri dikkati etkilemektedir. Gözlemciler önemli olduğuna inandıkları modelin etkinliklerine daha çok dikkat göstermektedirler (Schunk, çev. 2014). Türk atasözleri içinde öğrenmede model alınan kişinin yaptıklarının önemli olduğunu anlatan "Ağaca çıkan keçinin dala bakan oğlağı olur.” (Özdemir, 1984, s. 12) ve "Armut dalının dibine düşer.” (Aksoy, 1998, s. 153) gibi iki örnek vardır. İngiliz atasözlerinde de aynı anlama gelen "Erkek çocuk babasına çeker." (Like father, like son.) (Speake ve Simpson, 2008, s. 166) "Kız çocuk annesine çeker." (Like mother like daughter.) (Speake ve Simpson, 2008, s. 166) şeklinde iki örnekten söz edilebilir. Burada kalıtımla gelen benzerliğin yanı sıra, annebabanın çocuklarına model olarak gösterdikleri davranışların onlarda bıraktığı etki de kastedilmektedir. Yukarıdaki atasözleri anne-babanın çocukları için model olduğunu, çocukların ana-babalarında gördükleri davranışları yapmaya özenecekleri belirtilmektedir. Modellerin olumlu davranışlarını içselleştiren çocuklar, istendik özellikler kazanırken modellerin olumsuz davranışlarını örnek alan çocuklar, istenmeyen özelliklere sahip olurlar. Bu nedenle anne-babalar çocuklarına şunu yap, bunu yapma demek yerine, davranışlarıyla örnek olmalı; onlara olumlu ve olumsuz özellikler konusunda öğüt vermek yerine kendi yaşantılarıyla iyi-kötü, güzel-çirkin gibi kavramları kendi deneyimleriyle oluşturmalarına firsat vermelidirler.

\section{Yaparak-Yaşayarak Öğrenme}

Eğitim sürecinde öğrenenin etkin olmasının, öğrenmesi ve öğrendiklerinin kalıcı olmasındaki yeri büyüktür. Çünkü insanın yaşantıları duyu organlarını kullanmasıyla gerçekleşir. Bir konuyu öğrenmek amacıyla birey yaparak-yaşayarak deneyimler geçirirse daha çok duyu organını kullanır. Daha çok duyu organını kullanması ise yaşadıklarını algılamasını kolaylaştırır. Yaparak-yaşayarak öğrenme, Kolb’un Yaşantısal Öğrenme Modelinde ayrıştıran öğrenme stiline sahip bireylerin önemli bir özelliği olarak görülmektedir (Kolb, 2014). Arnas (2017), çocuk müzelerinin çocuklara yaparak-yaşayarak öğrenme firsatı sunan başlıca ortamlardan biri olarak çocuk gelişimini desteklediğini belirtmektedir. Öğretmen adaylarına göre de çocukların yaparak-yaşayarak öğrenmeleri için okul dışı ortamlar sınıf ortamına göre daha uygundur (Gürsoy, 2018). Yaparak-yaşayarak öğrenmenin yararlarını konu alan örnekleri çoğaltmak mümkündür. Günümüzde bir öğretim ilkesi haline gelmiş olan yaparak yaşayarak öğrenme, eskiden beri atasözlerine de konu olmuştur. Örneğin 
Türk atasözlerinde, "Bakmakla usta olunsa (öğrense) köpekler (kediler) kasap olurdu (kasaplığı öğrenirdi)." (Aksoy, 1998, s. 177); "Köpek suya düşmeyince yüzmeyi öğrenemez.” (Aksoy, 1998, s. 372) denilerek yaparak öğrenmenin önemi belirtilmiştir. İngiliz atasözlerinde ise; "Uygulama yapmak mükemmelleştirir." (Practice makes perfect.) (Speake ve Simpson, 2008, s. 397), "Deneyim en iyi ögretmendir." (Experience is the best teacher) (Speake ve Simpson, 2008, s. 157) sözleriyle de benzer bir düşünce dile getirilmiş̧ir. Yaparak-yaşayarak öğrenmenin önemini dolaylı olarak anlatan başka İngiliz atasözleri de vardır: "Girişim olmadan, gelişim olmaz." (Nothing venture, nothing gain) (Speake ve Simpson, 2008, s. 354); "Girişim olmadan hiçbir şeye sahip olamazsın." (Nothing venture, nothing have) (Speake ve Simpson, 2008, s. 354). Türk atasözleri de yaparak öğrenmenin gerekliğini anlatan örnekler bakımından zengindir. "Her düşüş bir öğreniş." (Özdemir, 1984, s. 106) ve "Bir musibet bin nasihatten yeğdir." (Aksoy, 1998, s. 198) gibi örnekler bunlardan bazılarıdır.

\section{Tartışma, Sonuç ve Öneriler}

Sözel ve yazılı iletişimin en güçlü kaynaklarından olan ve toplumların yüzyıllarca süren deneyim ve gözlemlerini çoğunlukla içinde değişmeceli bir anlam barındırarak anlatan atasözleri eğitsel bir içeriğe sahiptir. Ulusların kültürel değerleri ya da eğitim sistemleri birbirinden farklı olmasına karşın atasözleriyle yansıttıkları bu eğitsel söylemlerin pek çok ortak yönünün olduğu söylenebilir. Nitekim bu araştırmada da Türk ve İngiliz atasözleri çağdaş eğitim ilkeleri açısından incelenerek söz konusu ulusların eğitsel yaklaşımlarındaki benzerlik ve farklılıklar ortaya konulmuştur.

Türk ve İngiliz atasözlerinde çocukluk çağında verilen eğitimin önemine dair sunulan iletilerin çoğunun benzerlik gösterdiği söylenebilir. Örneğin, iki ulusa ait atasözlerinde de çocukluk çağında verilen eğitimin çocuğun kişilik gelişiminin temeli olduğuna ve belirli davranışların bu dönemde kazandırılması gerekliliğine benzetmeler kullanılarak dikkat çekilir. Gelişim psikologlarının belirttiği, çocuğun bazı davranışları kazanabilmesi (örneğin, konuşmayı öğrenmesi) için o davranışı kazanabileceği kritik dönemdeki yaşantıların önemi atasözleriyle kısaca anlatılır. Ayrıca çocukluk döneminde zaman yönetimi becerisinin kazanılması da önemli görülmektedir. Diğer yandan çocukluk çağının önemli bir öğrenme aracı olan oyunlar ile ilgili düşüncelere Türk atasözlerinde yer verilirken incelenen İngiliz atasözleriyle ilgili kaynaklarda bu konuyla ilgili atasözlerine rastlanılmamıştır.

Türk ve İngiliz atasözlerinde akıl ve bilgi kavramlarının oldukça önemsendiği görülmektedir. Akıl ve bilgi sahibi olmanın verimli bir yaşam sürmek için önemli bir güç olduğu, bilgisizlikten yarar beklenilemeyeceği ve bilginin başkalarına danışılarak kullanılması gerektiğine ilişkin ortak bir anlayışın olduğu anlaşılmaktadır. Ulusların atasözlerindeki benzer örneklerin olmasına karşın, bireylerin bilgi, beceri ve yeterliklerini sürekli geliştirme gereksiniminin vurgulandığ önemli bir öğrenme etkinliği olan yaşamboyu öğrenme konusuna ise yalnızca İngiliz atasözlerinde yer verildiği görülmektedir. Türkçede her ne kadar, Öğrenmenin yaşı yoktur gibi özlü 
sözler olsa da atasözlerinde yaşamboyu öğrenmenin önemini belirten bir atasözüne rastlanmamıştır.

Öğrenmeye hazır olma, güdülenme, pekiştirme ve ceza gibi öğrenmeyi kolaylaştıran veya engelleyen çeşitli etkenlerin önemi hem Türk hem de İngiliz atasözlerinde benzer biçimde vurgulanmıștır. Buna göre, bireyin duyuşsal olarak öğrenmeye güdülenmiş ve hazır olmasının bireyi harekete geçiren bir güç olduğuna ve pekiştirmenin istenilen davranışların kazanılması için etkili bir araç olabileceğine dair atasözleri vardır. Diğer yandan her iki ulusa ait atasözlerinde, cezanın bir disiplin aracı olarak kullanıldığı ve öğrenme üzerinde olumlu bir katkı sağladığına dair örnekler bulunmaktadır. Bu anlayışın şimdi geçerli olmasa da belirli bir döneme kadar iki toplumda da işlevselliğinin olduğu anlaşılmaktadır.

Her iki topluma ait atasözlerinde, öğrenenlere birlikte iş yapma becerisi kazandıran işbirlikli öğrenme anlayışına ilişkin ortak iletiler sunulmuştur. Ayrıca söz konusu uluslar, çocuğun etkileşimde bulunduğu sosyal çevrenin davranış kalıplarını taşıdığı gerçeği üzerinde de durmuşlardır. $\mathrm{Bu}$ nedenle çocuğun yakınındaki tüm yetişkinlerin kendi davranışlarını sorgulamaları ve örnek davranışlar sergilemeleri gerekmektedir.

Bireylerin öğrenme sürecinde etkin olmalarının önemini anlatan çok sayıda atasözü vardır. Yeni bilgi, beceri ve tutumların somut yaşantılarla kazanılmasının öğrenilenlerin kalıcılığını artırdığını belirten atasözlerindeki bu düşünce günümüzde bir öğretim ilkesi haline gelmiştir. Bu konudaki eğitsel deneyimler ve yapılan bilimsel çalışmalar, yaparak yaşayarak öğrenmeyi bilimsel bilgi haline getirmiştir. Türk ve İngiliz atasözlerindeki eğitsel söylemler karşılaştırmalı olarak incelendiğinde, her iki topluma ait atasözlerinin çağdaş eğitim ilkeleriyle büyük ölçüde örtüşen iletiler sunduğu ve böylece eğitsel bir işlevi yerine getirdikleri görülmektedir. Ayrıca araştırmada iki ulusun atasözlerinde yansıtılan eğitim anlayışının benzerlik gösterdiği anlaşılmaktadır. Atasözlerinin sahip oldukları eğitsel içeriğe bağlı olarak eğitimde kullanılmalarıyla ilgili şu öneriler yapılabilir:

Atasözlerinin sahip oldukları eğitsel içeriğe bağlı olarak eğitimde kullanılmalarıyla ilgili şu öneriler yapılmıştır: Atasözleri kapsamlı bir bilgiyi, bir tümceyle özetleyerek anlatmayı sağladığı için bilginin saklanması ve anımsanmasını kolaylaştırır. $\mathrm{Bu}$ nedenle eğitimciler tarafından yeri geldiğinde kullanılmalıdır. Öğrencilerin düşünme, yorumlama ve genelden özele akıl yürütme gücünü geliştirmek için de atasözlerinden yararlanılabilir.

Atasözleri insanlar arasındaki iletişimi geliştirmede kullanılabilir. İlettiklerinin doğrulukları genellikle tartışmasız kabul edildiği için ikna edicidirler. İletişimde bu özelliğinden yararlanılması anlatıma güç katar. Ayrıca eğitimle ilgili iletilere sahip atasözleri öğrencilerin eğitim ilkeleri ile ilgili farkındalıklarını arttırmayı destekleyerek eğitsel değerler oluşturmalarına yardım eder. Bu amaçla farklı ulusların atasözleri de kullanılabilir. 
Farklı ulusların atasözlerinde eğitimin odağındaki çocuğun sahip olması gereken değerler olan düşünme, sorgulama, merak etme gibi özellikleri içeren çok sayıda atasözü vardır. Farklı ulusların atasözleri incelenerek eğitsel değerlerin nasıl oluştuğu hakkında bilgi edinmek ve bir ulusun eğitim anlayışını anlamak için kullanılabilir.

\section{Kaynakça}

Aksan, D. (2014). Anadilimizin söz denizinde (3. Basım). Ankara: Bilgi Yayınevi.

Aksoy, Ö. A. (1998). Atasözleri ve deyimler sözlüğü. İstanbul: İnkılâp Kitapevi.

Arnas, Y. A. (2017). Oyun, öğrenme ve deneyimin birleşimi: Çocuk müzeleri. Yaratıcı Drama Dergisi, 12(2), 17-30. doi: 10.21612/yader.2017.010

Aş1lığlu, B. (2009). Türkçe öğretimi ve eğitim değerleri açısından Türk atasözleri üzerine bir inceleme. Çăgdaş Ĕ̆itim Dergisi, 34(362), 29-36.

Bakırcığlu, R. (2012). Ansiklopedik eğitim ve psikoloji sözlüğü. Ankara: Anı Yayıncilık.

Balkıs, M., Duru, E., Buluş, M. ve Duru, S. (2006). Üniversite öğrencilerinde akademik erteleme eğiliminin çeşitli değişkenler açısından incelenmesi. Ege Ĕgitim Dergisi, 7(2), 57-73. https://dergipark.org.tr/en/download/articlefile/57074 adresinden edinilmiştir.

Bayrakçı, M. (2007). Sosyal öğrenme kuramı ve eğitimde uygulanması. SAÜ Ĕ̆itim Fakültesi Dergisi, 14, 198-210. https://dergipark.org.tr/tr/download/articlefile/115558 adresinden edinilmiştir.

Bulut, M. (2013). Türkçe eğitimi ve öğretiminde dil ve kültür aktarımı aracı alarak atasözleri ve deyimlerin önemi. Turkish Studies, 8(13), 559-575. http://www.turkishstudies.net/files/turkishstudies/1483191380_34BulutMesutarm-559-575.pdf adresinden edinilmiştir.

Büyükkantarcıoğlu, N. (2006). Toplumsal gerçeklik ve dil. İstanbul: Multilingual.

Charles, C. M. (2003). Öğretmenler için Piaget ilkeleri [Teacher's petit Piaget]. (G. Ülgen, Çev.). Ankara: Nobel Yayın ve Dağıtım. (Orijinal kitabın yayım tarihi 1974).

Driscoll, M. P. (2012). Öğretim süreçleri ve öğrenme psikolojisi [Psychology of learning for instruction (3rd ed.)]. (Ö. F. Tutkun, Çev.). Ankara: Anı Yayıncılık. (Orijinal kitabın yayım tarihi 2005).

Erdamar, G. (2011). Yaşamboyu öğrenme. Ö. Demirel (Ed.), Eğitimde yeni yönelimler içinde (ss. 217-237). Ankara: Pegem Akademi Yayıncılık.

Fidan, N. (1986). Okulda öğrenme ve ögretme. Ankara: Kadıŏlu Matbaası. 
Gibbs Jr, R. W. (2001). Proverbial themes we live by. Poetics, 29(3), 167-188. doi: 10.1016/S0304-422X(01)00041-9

Gözpınar, H. (2014). The role of proverbs in forming intercultural awareness (on the basis of teaching English, Georgian and Turkish languages (Unpublished doctoral dissertation). Retrieved from https://files.eric.ed.gov/fulltext/ED594333.pdf

Gültekin, M. (2019). Sosyal bilişsel öğrenme kuramı. B. Oral (Ed.), Öğrenme öğretme kuram ve yaklaşımları içinde (ss. 111-147). Ankara: Pegem Akademi.

Gür, T. (2013). Post-modern bir araştırma yöntemi olarak söylem çözümlemesi. Journal of World of Turks, 5(1), 185-202. http://dieweltdertuerken.org/index.php/ZfWT/article/view/398/tahir_gur adresinden edinilmiştir.

Gürsoy, G. (2018). Fen öğretiminde okul dışı öğrenme ortamları. Turkish Studies, 13(11), 623-649. doi: 10.7827/TurkishStudies.13225

Honeck, R. P. (1997). A proverb in mind: The cognitive science of proverbial wit and wisdom. Mahwah, NJ: Lawrence Erlbaum Associates.

Ivanov, E. E., and Petrushevskaia, J. A. (2015). Etymology of English proverbs. Journal of Siberian Federal University, 5(8), 864-872. Retrieved from http://elib.sfu-kras.ru/bitstream/handle/2311/16817/06_Ivanov.pdf?sequence=1\&isAllowed=y

Karakuş, U. ve Keçe, M. (2012). Türk atasözlerinde doğal çevre algısı ve çevre eğitimi açısından önemi. Zeitschrift für die welt der Türken / Journal of World of Turks, 4(3), 131-145. http://www.dieweltdertuerken.org/index.php/ZfWT/article/view/380/karakus_k ece adresinden edinilmiştir.

Kızılkaya-Cumaoğlu, G. ve Diker-Coşkun, Y. (2012). Öğretmenlerin akademik erteleme davranışı ile teknoloji kullanım durumları arasındaki ilişki. International Periodical For The Languages, Literature and History of Turkish or Turkic, $7(4), \quad 2237-2247$. http://www.acarindex.com/dosyalar/makale/acarindex-1423933458.pdf adresinden edinilmiştir.

Knowles, M. (1996). Yetişkin öğrenenler: Göz ardı edilen bir kesim. Ankara: Ankara Üniversitesi Basımevi.

Koç, G. (2005). Yaşamboyu öğrenme. Ö. Demirel (Ed.), Eğitimde yeni yönelimler içinde (ss. 213-225). Ankara: PegemA Yayınları.

Kolb, D. (2014). Experiential learning: Experience as the source of learning and development (2nd ed.). New Jersey: Pearson Education.

Kurt, İ. (1997). Türk Atasözlerine psikolojik bir yaklaşım. Konya: Mikro Yayınları. 
Lauhakangas, O. (2007). Use of proverbs and narrative thought. Folklore: Electronic Journal of Folklore, 35, 77-84. doi: 10.7592/FEJF2007.35.lauhakangas

Maslow, A. H. (1954). Motivation and personality. New York: Harper and Row.

McCarthy, D. E., Baker, T. B., Minami, H. M., and Yeh, V. M. (2011). Applications of contemporary learning theory in the treatment of drug abuse. In T. R. Schachtman and S. Reilly (Ed.), Associative learning and conditioning theory: Human and non-human applications (pp. 235-269). New York: Oxford University Press.

Mieder, W. (2004). Proverbs: A handbook. Westport, Connecticut: Greenwood Press.

Miles, M. B., and Huberman, A. M. (2015). Nitel veri analizi [Qualitative data analysis: An expanded sourcebook]. (S. A. Altun ve A. A. Ersoy, Çev. Ed.). Ankara: Pegem Akademi. (Orijinal kitabın yayım tarihi 1994)

Oy, A. (1972). Tarih boyunca Türk atasözleri. İstanbul: Türkiye İş Bankası Kültür Yayınlar1.

Özdemir, E. (1984). Açıklamalı atasözleri sözlüğü (2. Bask1). İstanbul: Remzi Kitapevi.

Patton, M. Q. (2014). Nitel araştırma ve değerlendirme yöntemleri [Qualitative research and evaluation methods]. (M. Bütün ve S. B. Demir, Çev.). Ankara: Pegem Akademi (Orijinal kitabın yayın tarihi 2001).

Püsküllüoğlu, A. (2002). Türk atasözleri sözlüğü. Ankara: Arkadaş Yayınevi.

Schunk, D. H. (2014). Öğrenme teorileri: Eğitimsel bir bakış [Learning theories: An educational perspective]. (M. Şahin, Çev.). Ankara: Nobel Akademik Yayıncılık. (Orijinal kitabın yayım tarihi 2008)

Seker, S. E. (2015). Motivasyon teorisi (motivation theory). Ybs Ansiklopedisi, 2(1), 22-26, http://ybsansiklopedi.com/wpcontent/uploads/2015/03/motivasyonteorisi_yeniformat.pdf adresinden edinilmişstir.

Senemoğlu, N. (2013). Gelişim, ögrenme ve ögretim (19. Bask1). Ankara: Pegem Akademi.

Smith, W. G. (1936). Dictionary of English proverbs (Reprinted, with corrections) Oxford: At The Clarendon Press. Retrieved from https://archive.org/details/in.ernet.dli.2015.227228/page/n1

Sönmez, Ö. F. (2014). Atasözlerinin sosyal bilgiler programındaki değerler açısından incelenmesi. Journal of World of Turks, 6(2), 101-115. http://www.dieweltdertuerken.org/index.php/ZfWT/article/view/604/604 adresinden edinilmiştir. 
Sönmez, V. ve Alacapınar, G. F. (2014). Örneklendirilmiş bilimsel araştırma yöntemleri. Ankara: Anı Yayınc1lı.

Speake, J., and Simpson, J. (Ed.). (2008). The Oxford dictionary of proverbs. New York: Oxford University Press Inc.

Taşdelen, V. (2000). Türk atasözlerinde eğitim. A. Ü. Eğitim Bilimleri Fakültesi Dergisi, 33(1), 121-135. doi: 10.1501/Egifak_0000000035

Türk Dil Kurumu. (2009). Bölge ağızlarında atasözleri ve deyimler I-II. Ankara: Türk Dil Kurumu Yayınları.

Türk Dil Kurumu. (2019). Sözlükler: Atasözleri ve deyimler sözlüğü, https://sozluk.gov.tr/?kelime= adresinden edinilmiştir.

Türk Dil Kurumu. (2011). Türkçe sözlük (11. Basım). Ankara: Türk Dil Kurumu Yayınları.

Ün-Açıkgöz, K. (2005). Aktif öğrenme. İzmir: Eğitim Dünyası Yayınları.

Yapıcı, Ş. ve Yapıcı, M. (2005). Gelişim ve öğrenme psikolojisi. Ankara: Anı Yayıncilik.

Yaşar, F. Ö. (2007). Bilgi toplumu bağlamında Türk atasözlerinde "eğitim" ve "bilgi" kavramları üzerine düşünceler. Elektronik Sosyal Bilimler Dergisi, 5(19), 146158. http://www.acarindex.com/dosyalar/makale/acarindex-1423879318.pdf adresinden edinilmiştir.

Yazgan-İnanç, B., Bilgin, M. ve Kılıç-Atııı, M. (2007). Gelişim psikolojisi: Çocuk ve ergen gelişimi (3.Baskı). Ankara: PegemA Yayıncılık.

Yıldırım, A. ve Şimşek, H. (1999). Sosyal bilimlerde nitel araştırma yöntemleri, Ankara: Seçkin Yayınevi.

Yörükoğlu, A. (2006). Çocuk ruh sağlığı: Çocuğun kişilik gelişsimi eğitimi ve ruhsal sorunları (28. Basım). İstanbul: Özgür Yayınları.

Yurtbaşı, M. (1993). A dictionary of Turkish proverbs. Ankara: Turkish Daily News.

\section{Etik Kurul Kararı}

$\mathrm{Bu}$ araştırma, dergimize 01.01.2020 tarihinden önce gönderildiği için etik kurul kararı zorunluluğu taşımamaktadır. 



\title{
Educational Values in Turkish and English Proverbs
}

\begin{tabular}{cccc}
\hline ARTICLE TYPE & Received Date & Accepted Date & Published Date \\
Research Article & 07.06 .2020 & 07.08 .2020 & 07.08 .2020 \\
\hline
\end{tabular}

\author{
Bayram Aşılıoğlu (iD ${ }^{1}$ and Berivan Tokur Üner (iD) ${ }^{2}$ \\ Dicle University
}

\begin{abstract}
The aim of this study is to investigate Turkish and English proverbs comparatively in terms of their educational values. The study has been conducted through document analysis which is one of the qualitative research patterns. Dictionaries of Turkish and English proverbs have been examined to collect data. Initially, the proverbs conveying educational messages have been determined. Afterwards, educational messages in related proverbs have been coded with regard to educational subjects. Thus themes have been created by choosing identified codes that were relevant to each other. Given to investigated Turkish and English Proverbs Dictionaries within the scope of this study, it has been observed that proverbs have common educational messages such as: The importance of education in childhood, the importance of wisdom and its relationship with education, the effects of motivation on learning, learning by practising and living, cooperation, the significance of the interaction and model learning throughout the education process, reward and punishment in education. On the other hand, while lifelong learning has been mentioned in English proverbs, this theme hasn't been observed in Turkish proverbs. As a consequence, it is seen that there is a considerable amount of similarity between both nations' proverbs with regard to the reflection of today's sense of education.
\end{abstract}

Keywords: Proverb, educational values, culture, lifelong learning.

${ }^{1}$ Corresponding Author: Assoc. Prof., Ziya Gökalp Educational Faculty, Department of Educational Sciences, Division of Curriculum and Instruction, E-mail: bayramasilioglu@gmail.com, https://orcid.org/0000-0002-2425-0624

${ }^{2} \mathrm{Ph} . \mathrm{D}$. Student, Institute of Educational Sciences, Department of Educational Sciences, Division of Curriculum and Instruction, E-mail: berivan.tokur@ hotmail.com, https://orcid.org/0000-0002-3777-5606 


\section{Purpose and Significance}

The aim of this study is to investigate Turkish and English proverbs comparatively in terms of their educational values. The educational messages in Turkish and English proverbs were analyzed in order to achieve this target. The proverbs of both nations were examined in terms of generally accepted educational theories, principles and approaches. It is aimed to present the similarities and differences between both nations' teaching philosophies on the basis of relevant analyzing. The following questions were searched to reach the study's aims:

1. What are the main proverbs in Turkish and English proverbs that have an educational message directly or indirectly?

2. How are the messages in both nations' proverbs correlated to educational dimensions?

3. According to both nations' proverbs, in what aspects do the values in educational dimensions show similarities and differences?

\section{Method}

The study was conducted through document analysis which is one of the qualitative research patterns. Dictionaries of Turkish and English proverbs were examined to collect data. First of all, the proverbs conveying educational messages were determined. Then educational messages in related proverbs were coded according to educational subjects. After that themes were created by choosing identified codes that were relevant to each other. The data was collected and coded separately by two researchers and brought together under common categories. The consistency coefficient between two researchers was calculated as .92. Additionally, expert opinions on chosen categories were provided to achieve validity.

\section{Results}

The proverbs which are one of the most powerful sources of verbal and written communication have also an educational content. In this study, the proverbs of Turkish and English nations were examined according to educational principles and the similarities and differences of both nations' educational philosophies were presented.

It can be said that the messages conveyed with proverbs on the importance of education which should be provided in childhood show similarities. The common message of both nations' proverbs is that the education provided in childhood has a basis for a child's personality development. It is also quite necessary to make use of critical learning opportunities on time to make children acquire certain behaviors. It is also seen to be important to help the child achieve time management skills in childhood.

One of the other important subjects on education in childhood is playing games. The game is an educational environment that provides children to reveal their learning 
potential. It is seen that the ideas stressing the necessity and significance of games in childhood are available in Turkish proverbs, on the other hand; it is not mentioned in English proverbs considering the English references.

There are many English and Turkish proverbs on the subjects of wisdom and knowledge, which are the main tools and environment of education. Knowledge is one of the fundamental concepts of philosophy which is accepted as a basis of science. Mankind has been in a search of defining what the real knowledge is and how it is acquired since ancient times. Knowledge is an important part of educational process, as well. All the covered information serves to construct new concepts through new experiences and helps to make the life easier.

It is defined in Turkish and English proverbs through different metaphors as having knowledge means being powerful and the most valuable thing that human can ever have is wisdom. For instance, there are some proverbs in our culture such as "Wisdom is not sold for money" (Akıl para ile satılmaz) (Yurtbaş1, 1993, p. 390) and "Wisdom is a fund for someone" (Ak1l kişiye sermayedir) (Oy, 1972). Likewise, in English proverbs wisdom is seen as an important possession. "Without wisdom wealth is worthless" (Smith, 1936, p. 594) is an example of it. What is emphasized in both nations' proverbs is that wisdom is better than having a lot of money and it is the main source of all kinds of gains.

The power of thinking and learning, which distinguishes people from the other living beings, keeps going from birth till death without paying attention where it happens. Lifelong learning term emphasizes that learning can happen at any time and anywhere. According to this understanding, a person maintains his personal, social and professional development naturally and continuously for life. We can see that the notion of lifelong learning dates back to old times considering the examples available in English proverbs. English proverbs such as "It's never too late to learn” (Öğrenmek için asla geç değildir.) (Speake and Simpson, 2008, p. 341), "Never too old to learn" (Öğrenemeyecek kadar yaşlanamazsın) (Speake and Simpson, 2008, p. 274) state that learning goes on lifelong. It is understood that lifelong learning term was stated in English proverbs, however; it is not the same for Turkish proverbs. Any proverbs describing the importance of lifelong learning were not found in Turkish references.

There are a lot of factors affecting learning. While some of them are used to make learners awake for learning, the others are used to make learned subjects permanent. Learning a subject forms a basis for subsequent learning. In English proverbs, "Nothing succeeds like success" (Başarı başarıyı getirir) (Speake and Simpson, 2008, p. 353) saying emphasizes the importance of readiness to learn cognitively. On the other side, "Without devotion there is no genius" (Aşk olmadan meşk olmaz) (Yurtbaşı, 1993, p. 238) is a Turkish proverb stating that readiness to learn effectively is the first step motivating a person to take part in learning process. It is also important to be open to new experiences and take risks while learning. This situation is summarized in English proverbs as "You can't make an omelet without breaking eggs." (Yumurtaları kırmadan omlet yapamazsın) (Speake and Simpson, 
2008, p. 360) The same thing happens in Turkish proverbs, too. The proverbs of both nations view a person's taking active roles in learning as crucial.

There are some examples of proverbs both in Turkish and English sayings stating that punishments and especially corporal punishments can be used to turn the behaviors into the intended ones. The English proverb "Spare the rod and spoil the child” (Sopayı sakla çocuğu şımart.) (Speake and Simpson, 2008, p. 447) is the example of it. It can be understood that it was seen as a usual behavior to help children learn something through corporal punishments until a certain time. However, it is not an acceptable behavior type for teachers in today's world for both nations.

Education is an interactive process. People must communicate with other people. As a result of this interaction, a person can learn something from others or teach them and they sometimes work cooperatively. It is a commonly accepted approach that a single person can deal with hard problems much more easily with the help of other people. It can be examined in both Turkish and English proverbs how cooperation makes the life of a person easier. It is also an important educational value that every learner should acquire.

There are many Turkish and English proverbs emphasizing behavioral changes happening as a result of this interaction. "The rotten apple injures its neighbor" (Çürük elma yanındakileri de bozar) (Speake and Simpson, 2008, p. 412), "A man is known by the company he keeps" (Kişi arkadaşıyla bilinir.) (Speake and Simpson, 2008, p. 88) are the examples stating that if a person makes friendship with a bad-tempered one, he will pick up bad habits. There are also many Turkish and English proverbs underlining the importance of model learning and its impact on learners. The Turkish proverb "The pear doesn't fall away from its tree" (Armut dalının dibine düşer) (Aksoy, 1998) and English proverbs "Like father, like son" (Erkek çocuk babasına çeker.) (Speake and Simpson, 2008, p. 166), "Like mother like daughter" (K1z çocuk annesine çeker.) (Speake and Simpson, 2008, p. 166) have the same meaning. These sayings imply how parents' behaviors affect their children for better or for worse. If a child exposes to his model's good behavioral pattern, he will acquire required types of actions, on the other side; if he takes examples of his model's negative behavior, unfortunately, he will imitate the same thing. So, it is crucial for parents to be good role models for their children.

Involving actively in learning process makes learned subjects permanent. The more sense organs a person uses, the more permanently learning takes place. If he learns something through experiences, he will acquire the intended skills for a long time. Learning by experiences, which is a teaching principle now, has been mentioned in Turkish and English proverbs since the ancient times. For instance, "Example is better than precept" (Bir musibet bin nasihatten yeğdir.) (Aksoy, 1998) is a Turkish proverb stressing the necessity of experiences for learning. Additionally, "Practice makes perfect" (Uygulama yapmak mükemmelleştirir.) (Speake and Simpson, 2008, p. 397) and "Experience is the best teacher" (Deneyim en iyi ögretmendir.) (Speake and Simpson, 2008, p. 157) are English proverbs that express a similar thought. 


\section{Discussion and Conclusions}

The following ideas in Turkish and English proverbs are seen to be important: The education provided in the childhood is quite important. Having wisdom equals to being powerful. Lifelong learning is only mentioned in English proverbs. It can be explained by the fact that learning occurring in childhood and adulthood is regarded as efficient enough in Turkish culture. Readiness to learn, motivation, reinforcements and punishments are the factors affecting learning. Cooperation, interaction and model learning are key concepts in learning process. It is quite necessary for learners to take part actively in learning process in order to make learned subjects permanent. As a consequence, it is seen that both nations' proverbs reflect ideas that are mostly in accord with today's sense of education. It can be also concluded that the educational messages conveyed with proverbs have lots of things in common even though both Turkish and English nations have different systems of education and cultural values. It is also seen that the proverbs of these nations perform an educational function considering the ideas reflected through them.

Educators can use proverbs to enhance students' awareness about principles of education. There are a lot of proverbs emphasizing the power of thinking, questioning and curiosity. These proverbs can be used in daily conversations to make people aware of the significance of scientific thinking.

\section{The Ethical Committee Approval}

The ethical committee approval is not compulsory for this research because it was sent to our journal before 01.01.2020. 